\title{
MODEL PENGUKURAN KINERJA KARYAWAN BERDASARKAN KOMITMEN, MOTIVASI KERJA DAN GAYA KEPEMIMPINAN
}

\author{
Rahmat Basuki ${ }^{1}$, Anton Agus Setyawan² dan M Farid Wajdi ${ }^{3}$ \\ 1Fakultas Teknik, Universitas Sebelas Maret Surakarta, 23Fakultas Ekonomi dan Bisnis \\ Universitas Muhammadiyah Surakarta \\ anton.setyawan@ums.ac.id
}

\begin{abstract}
This study aims to measure the effect of leadership styles, organizational commitment to performance with the mediation of motivation in the civil service of the Faculty of Universities in Surakarta. The study population was a civil servant employees in the faculty. The sample is determined by the saturated sample technique, the entire employee staff respondents as many as 76 people. Methods of data collection techniques used are questionnaire. Data analysis method used is the method of path analysis (path analysis). From the results of this study concluded that the style of leadership, organizational commitment and motivation of jointly have a significant influence on employee performance. While the results of the t test of leadership style variable result that leadership style has no effect on the motivation and performance of the organization's commitment and motivation. Variabel partially have a significant influence on employee performance. With the result that the path analysis variables mediate motivational leadership style on employee performance. Motivation also mediate organizational commitment to employee performance. Judging from the coefficient (R Square) we can conclude that the motivation was influenced variable leadership style and organizational commitment of $0.46 \%$ while the rest influenced by other factors beyond the study variables. Performance is influenced by the motivation of employees by $44 \%$ and the rest influenced by other factors beyond the variables. Performance of employees affected by variables of leadership style and organizational commitment by $36 \%$ while $64 \%$ is variable - the other variables outside the study.
\end{abstract}

Keywords: Leadership Style, Organizational Commitment, Motivation, Employee Performance.

Abstrak: Penelitian ini bertujuan untuk mengukur pengaruh gaya kepemimpinan, komitmen organisasi terhadap kinerja denganmediasi motivasi padapegawai negeri sipil satu Fakultas Perguruan Tinggi Negeri di Surakarta. Populasi penelitian adalah karyawan pegawai negeri sipil di satu fakultas. Sampel ditentukan dengan teknik sampel jenuh, dengan responden seluruh pegawai staff sebanyak 76 orang. Metode pengumpulan data yang digunakan adalah teknik Kuesioner. Metode analisis data yang digunakan adalah metode analisis jalur (Path Analysis). Dari hasil penelitian dapat disimpulkan bahwa gaya kepemimpinan, komitmen organisasi dan motivasi secara bersama-sama mempunyai pengaruh yang signifikan terhadap kinerja pegawai. Sedangkan hasil uji t dari variabel gaya kepemimpinan diperoleh hasil bahwa gaya kepemimpinan tidak mempunyai pengaruh terhadap motivasi dan kinerja pegawai.Variabel Komitmen organisasi dan motivasi secara parsial mempunyai pengaruh signifikan terhadap kinerja pegawai. Dengan analisisjalurdiperoleh hasilbahwa variabel motivasi memediasi gaya kepemimpinan terhadap kinerja pegawai. Motivasi juga memediasi komitmen organisasi terhadap kinerja 
pegawai.Dilihat dari nilai koefisien ( $\mathrm{R}$ Square) dapat disimpulkan bahwa motivasi dipengaruhi variable gaya kepemimpinan dan komitmen organisasi sebesar 0,46\% sedangkan sisanya dipengaruhi oleh faktor lain diluar variabel penelitian ini.Kinerja pegawai dipengaruhi oleh motivasi sebesar $44 \%$ dan sisanya dipengaruhi oleh faktor lain diluar variabel penelitian. Kinerja pegawai dipengaruhi oleh variabel gaya kepemimpinan dan komitmen organisasi sebesar 36\% sedangkan $64 \%$ adalah variabel - variabel lain diluar penelitian ini.

Kata Kunci: Gaya Kepemimpin, Komitmen Organisasi, Motivasi, Kinerja Pegawai.

\section{PENDAHULUAN}

Kajian tentang pengukuran kinerja karyawan merupakan issue di dalam manajemen sumber daya manusia yang dianggap memberikan kontribusi penting terkait dengan daya saing organisasi (Nasomboon, 2014; Nerid, 2014). Kinerja karyawan adalah hasil dari aktivitas mereka dalam melaksanakan tugas baik dari segi kualitas maupun kuantitas berdasarkan standar kerja yang telah ditentukan dapat menjadi acuan bagi pimpinan untuk menentukan strategi yang efektif dan efisien demi tercapainya tujuan organisasi.

Tujuan organisasi dapat tercapai dengan baik jika pimpinan dapat mengelola aktivitas manajemen bawahan serta melaksanakan fungsi manajemen yaitu: perencanaan, pengarahan, pengorganisasian dan kontrol. Dalam memimpin setiap pemimpin memiliki pola kepemimpinan yang berbeda-beda dalam menggerakkan dan mengarahkan setiap pegawainya. Pola ini dapat digunakan seorang pemimpin untuk mempengaruhi perilaku orang lain. Masing-masing pola tersebut memiliki keunggulan dan kelemahan. Menurut (Sukarno Marzuki, 2002) seorang pemimpin secara umum akan menggunakan gaya kepemimpinan sesuai dengan kemampuan dan kepribadiannya.

Pemimpin yang baik akan melihat dan mendengar setiap kondisi pegawai atau bawahannya. Pemimpin harus dapat menggugah empati pegawai ,sehingga akan menimbulkan persepsi yang baik terhadap pimpinan. Apabila persepsi terhadap pimpinan telah terbentuk, bahwa pimpinan menunjukan sikap yang dapat dipercaya, dicintai dan sanggup membimbing, maka secara otomatis pegawai akan menghormati pimpinan dan melaksakan tugas denagn penuh tanggung jawab. Ketika gaya kepemimpinan dibangun dan diperkuat oleh motivasi yang diberikan, maka komitmen pegawai terhadap organisasi otomatis akan terbentuk dengan sendirinya dan kinerja diyakini dapat dengan mudah diwujudkan.

Tingkat absensi pegawai sangat mempengaruhi keberhasilan tujuan organisasi. Absensi yang tinggi dari pegawai menyebabkan pelayanan kepada pengguna, keterlambatan dalam penyelesaian tugas serta menghambat penyelenggaran pemerintah dibidang pendidikan tinggi. Tugas pemimpin harus tegas dan cakap kepada pegawai,karena sangat menentukan kualitas kinerja pegawai dan mendorong meningkatnya komitmen organisasi sehingga kinerja pegawai juga akan meningkat. Motivasi juga sangat dibutuhkan karena dapat meningkatkan kemampuan kerja untuk menyelesaikan tugas sehingga kinerja pegawai akan meningkat. Secara kuantitatif indikasi adanya penurunan kinerja pegawai dapat ditunjukkan oleh tingginya tingkat absensi atau ketidakhadiran pegawai .

Berdasarkan data kepegawaian salah satu Fakultas PTN di Surakarta tahun 2016 pada tahun 2013-2015 dari bulan Januari hingga Desember dapat diketahui bahwa jumlah 
pegawai yang absen cukup tinggi dengan prosentase kehadiran $7.3 \%$ yang terjadi pada bulan Desember tahun 2015 dan terendah pada bulan Januari tahun 2014 dengan $0.8 \%$. Pada tahun 2015 dapat dilihat bahwa terjadi kecenderungan tingkat absensi pegawai meningkat dibandingkan bulan sebelumnya, dan terjadi peningkatan juga jika dilihat dari tahun sebelumnya.

Dari apa yang telah dikemukakan diatas, penulis melakukan penelitian bagaimana faktor gaya kepemimpinan yang, motivasi kerja dan komitmen orgainisasi dapat memberikan kontribusi atau pengaruh terhadap kinerja pegawai, yang pada akhirnya mempengaruhi kinerja pegawai, maka penulis mengambil judul " Pengaruh Gaya kepemimpinan dan komitmen organisasi terhadap kinerja dengan mediasi motivasi.

Penelitian ini mempunyai tujuan umum untuk mengukur pengaruh gaya kepemimpinan, komitmen organisasi terhadap kinerja pegawai dengan pemediasi motivasi kerja selanjutnya terperinci untuk: (1) Untuk menganalisi pengaruh gaya kepemimpinan terhadap kinerja pegawai; (2) Untuk menganalisis pengaruh komitmen organisasi terhadap kinerja pegawai; (3) Untuk menganalisis pengaruh gaya kepemimpinan terhadap motivasi; (4) Untuk menganalisis pengaruh komitmen organisasi terhadap motivasi; (5) Untuk menganalisis pengaruh motivasi terhadap kinerja pegawai; (6) Untuk menganalisis pengaruh gaya kepemimpinan dan komitmen organisasi terhadap kinerja pegawai dengan mediasi motivasi kerja.

\section{KAJIAN TEORI}

Gaya Kepemimpinan dalam Organisasi. Gaya kepemimpinan adalah perilaku dan strategi, sebagai hasil kombinasi dari falsafah, ketrampilan, sifat, sikap, yang sering diterapkan seorang pemimpin ketika ia mencoba mempengaruhi kinerja bawahannya Tampubolon (2007). Gaya kepemimpinan sendiri merupakan suatu bentuk pendekatan yang digunakan untuk memahami bawahannya. Kesesuaian antara gaya kepemimpinan, norma-norma dan kultur organisasi dipandang sebagai suatu prasyarat dari kunci sebuah kesuksesan serta pencapaian prestasi tujuan organisasi (Yulk, 1989).

Pemimpin yang efektif dalam dalam menerapkan gaya kepemiminan tertentu harus memahami siapa bawahan yang dipimpinnya, mengerti kekuatan dan kelemahan serta mengetahui bagaimana cara memanfaatkan kekuatan bawahannya untuk mengimbangi kelemahan yang mereka miliki. Seorang pemimpin harus dapat mengubah cara pandang bawahan terhadap suatu tugas yang merupakan kewajiban dan tanggung jawabnya. Dengan gaya kepemimpinannya maka seorang pimpinan harus dapat menjadi motivasi untuk melaksanakan tugasnya dengan baik.

Motivasi dan Komitmen Karyawan. Motivasi kerja pegawai sangat tergantung kepada motivasi dan perilaku kerja pimpinan (Risambessy dan Swasto, 2012). Jika seorang pemimpin bersungguh-sungguh dan penuh komitmen untuk melaksakan suatu pekerjaan, maka secara langsung pegawai atau bawahan akan termotivasi untuk membantu pimpinan dalam melaksakan tujuan organisasi. Sikap posistif dan keteladanan pimpinan juga menciptakan dan membangkitkan loyalitas kepada pimpinan dan kepada organisasi.

Komitmen orgainsasi merupakan usaha untuk mengidentifikasikan diri dan melibatkan diri dalam organisasi dan berharap tetap menjadi anggota organisasi (Robbin,2000). Komitmen organisasi diperlukan sebagai salah satu hal yang mempengaruhi kinerja pegawai. Komitmen organisasi pada pegawai yang tinggi biasanya 
akan meningkatkan kinerja yang tinggi dan sekaligus dapat menurunkan tingkat absensi dan sebaliknya jika seorang pegawai memiliki tingkat komitnen rendah maka kinerjanya juga rendah (Nyhan,1999). Dalam penelitian terkini tentang komitmen pimpinan akan mempengaruhi kinerja.

Perilaku pemimpin yang berkomitmen terhadap organisasi mereka, bekerja menuju organisasi keberhasilan sasaran, dengan fokus pada pencapaian tujuan, danjuga bekerja menuju keberhasilan perubahan organisasi, mempengaruhinilai kinerja organisasi serta tingkat keterlibatan karyawan (Boonyada Nasomboon, 2014). Peran seorang pemimpin diperlukan dalam mengarahkan bawahan untuk mencapai kesuksesan sesuai tujuan organisasi.

Menurut (Peter dan John: 2004), gaya pemimpin sangat berpengaruh kepada kesuksesan dan kegagalan sebuah organisasi. Peran seorang pemimpinn diperlukan dalam mengarahkan bawahan mencapai kesuksesan sesuai tujuan organisasi. Pemimpin berkemampuan untuk bisa mempengaruhi pengikutnya agar bertindak sesuai dengan tujuan organisasi. Menurut Nurjanah (2013), gaya kepemimpinan secara langsung mempengaruhi kinerja pegawai. Salah satu faktor untuk mempengaruhi kinerja pegawai adalah motivasi kerja. Motivasi kerja dapat menumbuhkan kekuatan identitas, dan dengan keterlibatan pegawai dalam suatu organisasi akan timbul komitmen yang besar dalam mencapai tujuan organisasi. Dengan komitmen pegawai yang tinggi maka secara langsung kinerja pegawai akan meningkat.

Kinerja Karyawan. Kinerja adalah hasil kerja secara kualitas dan kuantitas yang dicapai oleh seorang pegawai dalam melaksanakan tugasnya sesuai dengan tanggung jawab yang diberikan kepadanya (Mangkunegara,2001).

Desler (2006) memberikan contoh kriteria penilaian kinerja pegawai meliputi kualitas, produktivitas (kualitas serta efisien), pekerjaan dengan menggunakan ilmu pengetahuan yang terukur. Pengukuran kinerja pegawai akan dapat berguna untuk: (1) Mendorong orang agar berperilaku positif atau memperbaiki tindakan mereka yang berada dibawah standar kerja; (2) Sebagai bahan penilaian bagi pihak pimpinan apakah mereka telah bekerja dengan baik; (3) Memberikan dasar yang kuat bagi pembuatan kebijakan untuk peningkatan organisasi.

Pendekatan Penelitian. Menurut (Hadi, 2000), populasi adalah semua obyek, semua gejala dan semua kejadian atau peristiwa yang akan dipilih harus sesuai dengan masalah yang akan di teliti. Populasi dalam penelitian ini adalah pegawai/karyawan Pegawai Negeri Sipil di satu Fakultas PTN di Surakarta.

Sampel adalah bagian dari jumlah dan karakteristik yang dimiliki oleh populasi (Sugiyono,2009). Jumlah Karyawan Pegawai Negeri Sipil di Fakultas ini menurut data kepegawaian yang aktif tahun 2015 adalah berjumlah kurang dari 100 orang yaitu 81 orang, dengan jumlah Staff 76 orang dan pejabat struktural adalah 5 orang. Metode Analisis Data yang digunakan dalam penelitian ini adalah dengan menggunakan Path Analysis / Analisis Jalur.

\section{HASIL DAN PEMBAHASAN}

Berdasarkan Tabel 1 dapat dilihat dan diintepretasikan besarnya dari masing-masing sebagai berikut: 
a. Model 1, berdasarkan hasil analisa data diperoleh nilai thitung untuk variabel $\mathrm{X}_{1}$ sebesar 0,231 sedangkan $t_{\text {table }}$ sebesar 1,993 maka $t_{\text {hitung }}(0,231)<t_{\text {tabel }}(1,993)$. Hal ini diperkuat dengan nilai signifikan 0,818 $(0,818>0,05)$, Dengan demikian dapat disimpulkan bahwa gaya kepemimpinan mempunyai pengaruh positif tidak signifikan terhadap motivasi.

Tabel 1. Hasil Uji t dan F

\begin{tabular}{clccccc}
\hline Model & \multicolumn{1}{c}{ Variabel } & $\mathrm{t}$ & $\mathrm{Sig}$ & $\mathrm{F}$ & $\mathrm{Sig}$ & R Square \\
\hline \multirow{2}{*}{1} & Constant & 5.022 & 0.000 & & & \\
& X1 Gaya Kepemimpinan & 0.231 & 0.818 & 32.287 & 0.000 & 0.469 \\
& X2 Komitmen Organisasi & 6.714 & 0.000 & & & \\
& Constant & 4.371 & 0.000 & & & \\
2 & Z Motivasi Kerja & 7.653 & 0.000 & 58.575 & 0.000 & 0.442 \\
3 & Constant & 5.694 & 0.000 & & & \\
& X1 Gaya Kepemimpinan & 0.702 & 0.485 & 21.159 & & \\
& X2 Komitmen Organisasi & 5.134 & 0.000 & & & \\
\hline
\end{tabular}

Variabel X2, yaitu komitmen organisasi mempunyai nilai $t_{\text {hitung }}$ untuk variabel $\mathrm{X}_{2}$ sebesar 6,714 sedangkan $t_{\text {table }}$ sebesar 1,993 maka $t_{\text {hitung }}(6,714)>t_{\text {tabel }}(1,993)$. Hal ini diperkuat dengan nilai signifikan 0,000 $(0,000<0,05)$, Dengan demikian dapat disimpulkan bahwa komitmen organisasi mempunyai pengaruh positifsignifikan terhadap motivasi.

b. Model 2, berdasarkan hasil analisa data diperoleh nilai thitung untuk variabel $\mathrm{Z}$ diperoleh nilai $t_{\text {hitung }}$ untuk variabel $\mathrm{Z}$ sebesar 7,653, sedangkan $t_{\text {table }}$ sebesar 1,993 maka $t_{\text {hitung }}(7,653)>t_{\text {tabel }}(1,993)$. Hal ini diperkuat dengan nilai signifikan $0,000(0,000<0,05)$, maka dapat disimpulkan bahwa motivasi mempunyai pengaruh positif signifikan terhadap kinerja pegawai.

c. Model 3, berdasarkan hasil analisa data diperoleh nilai thitung untuk variabel $\mathrm{X}_{1}$ diperoleh nilai $t_{\text {hitung }}$ untuk variabel $X_{1}$ sebesar 0,702, sedangkan $t_{\text {table }}$ sebesar 1,993 maka $t_{\text {hitung }}(0,702)<t_{\text {tabel }}(1,993)$. Hal ini diperkuat dengan nilai signifikan $0,485(0,485>$ $0,05)$, Demikian dapat disimpulkan bahwa gaya kepemimpinan mempunyai pengaruh positif tidak signifikan terhadap kinerja pegawai

Dalam model 3, variabelX $X_{2}$ yaitu variabel komitmen organisasi mempunyai nilai $t_{\text {hitung }}$ untuk variabel $X_{2}$ sebesar 5,134 sedangkan $t_{\text {table }}$ sebesar 1,993 maka $t_{\text {hitung }}(5,134)>t_{\text {tabel }}$ $(1,993)$. Hal ini diperkuat dengan nilai signifikan 0,000 $(0,000<0,05)$, Dengan demikian dapat disimpulkan bahwa komitmen organisasi mempunyai pengaruh positifyang signifikan terhadap kinerja pegawai.

Untuk uji F, berdasarkan tabel dalam model 1 dapat dilihat bahwa nilai $F_{\text {hitung }}$ diperoleh sebesar 32,287 lebih besar dari $F_{\text {tabel }}(3,15)$, hal ini juga diperkuat dengan nilai taraf signifikan sisebesar 0,000 atau signifikansi yang diperoleh lebih kecil dari $\alpha=0,05$, artinya $\mathrm{H}_{0}$ ditolak $\mathrm{H}_{\mathrm{a}}$ diterima. Maka dapat disimpulkan bahwa variabel gaya kepemimpinan dan komitmen organisasi, secara simultan mempunyai pengaruh yang signifikan terhadap motivasi kerja pegawai.

Berdasarkan analisis model 2 dapat dilihat bahwa nilai $F_{\text {hitung }}$ diperoleh sebesar 58,575 lebih besar dari $F_{\text {tabel }}(3,15)$, hal ini juga diperkuat dengan nilai taraf signifikansi sebesar 0,000 atau signifikansi yang diperoleh lebih kecil dari $\alpha=0,05$, artinya $\mathrm{H}_{0}$ ditolak $\mathrm{H}_{\mathrm{a}}$ diterima. Maka dapat disimpulkan bahwa variabel motivasi, secara simultan mempunyai pengaruh yang signifikan terhadap kinerja pegawai. 
Dalam model 3 dapat dilihat bahwa nilai $F_{\text {hitung }}$ diperoleh sebesar 21,159 lebih besar dari $F_{\text {tabel }}(3,15)$, hal ini juga diperkuat dengan nilaitarafsignifikansisebesar 0,000atausignifikansi yang diperolehlebihkecil dari $\alpha=0,05$, artinya $\mathrm{H}_{0}$ ditolak $\mathrm{H}_{\mathrm{a}}$ diterima. Maka dapat disimpulkan bahwa variabel gaya kepemimpinan dan komitmen organisasi, secara simultan mempunyai pengaruh yang signifikan terhadap kinerja pegawai.

Tabel 2. Model Estimasi Pengujian Hipotesis

\begin{tabular}{clcccc}
\hline \multirow{2}{*}{ Model } & \multicolumn{1}{c}{ Variabel } & $\begin{array}{c}\text { Unstandardized } \\
\text { Coefficients }\end{array}$ & $\begin{array}{c}\text { Standardized } \\
\text { Coefficients } \\
\text { Beta }\end{array}$ & t & Sig \\
\hline \multirow{2}{*}{1} & Constant & 9.683 & & 5.022 & 0.000 \\
& X1 Gaya Kepemimpinan & 0.016 & 0.023 & 0.231 & 0.818 \\
& X2 Komitmen Organisasi & 0.587 & 0.673 & 6.714 & 0.000 \\
2 & Constant & 8.597 & & 4.371 & 0.000 \\
& Z Motivasi Kerja & 0.634 & 0.665 & 7.653 & 0.000 \\
& Constant & 11.430 & & 5.694 & 0.000 \\
& X1 Gaya Kepemimpinan & 0.052 & 0.077 & 0.702 & 0.485 \\
& X2 Komitmen Organisasi & 0.467 & 0.562 & 5.134 & 0.000 \\
\hline
\end{tabular}

Model 1

$$
\begin{aligned}
\mathrm{Z}= & \mathrm{a}_{0}+\mathrm{a}_{1} \mathrm{X}_{1}+\mathrm{a}_{2} \mathrm{X}_{2}+\mathrm{e} \\
= & 9.683+0.016 \mathrm{X} 1+0.587 \mathrm{X} 2 \\
& \text { Model } 2 \\
\mathrm{Y}= & \mathrm{c}_{0}+\mathrm{c}_{1} \mathrm{Z}_{1}+\mathrm{e} \\
= & 8.597+0.634 \mathrm{Z} \text {...............Model } 1 \\
& \text { Model } 3 \\
\mathrm{Y}= & \mathrm{b}_{0}+\mathrm{b}_{1} \mathrm{X}_{1}+\mathrm{b}_{2} \mathrm{X}_{2}+\mathrm{e} \quad \ldots \ldots \ldots \ldots . . \text { Model } 3 \\
= & 11.430+0.052 \mathrm{X} 1+0.467 \mathrm{X} 2
\end{aligned}
$$

Berdasarkan pada model persamaan diatas maka dapat digambarkan dalam bentuk struktural regresi (Path Analysis) sebagai berikut:

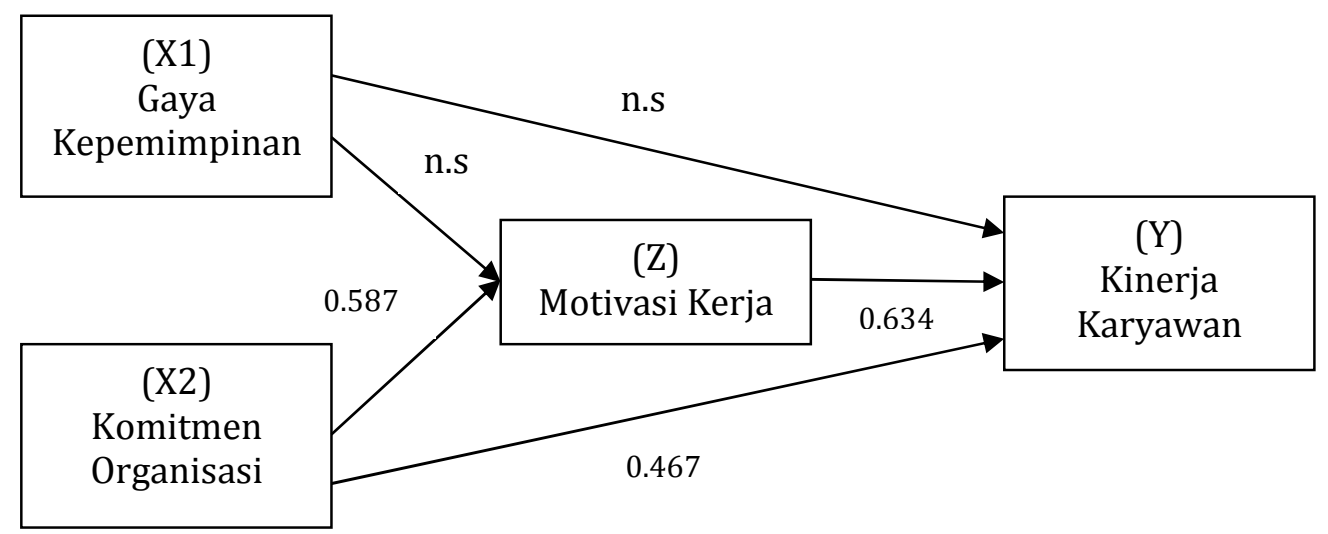

Gambar 1. Path Analysis

Model 1. Berdasarkan analisis model 1, sebagai variabel independen adalah gaya kepemimpinan dan komitmen organisasi serta variabel dependen adalah motivasi kerja. 
Diperoleh nilai $\mathrm{R}^{2}$ sebesar 0.469 , hal ini menunjukkan bahwa variable independen yaitu gaya kepemimpinan dan komitmen organisasi hanya mampu menjelaskan variable dependen yaitu motivasi kerja sebesar $46.9 \%$ sementara siasanya yaitu $53.1 \%$ adalah diluar variabel dalam penelitian ini.

Pertama. Pengaruh gaya kepemimpinan terhadap motivasi kerja karyawan. Pengaruh gaya kepemimpinan terhadap motivasi kerja karyawan dalam penelitian ini adalah berpengaruh positif dan tidak signifikan dengan nilai koefisien 0.016 pada $p<0.05$, yaitu 0.818 lebih besar dari 0.05 maka dapat disimpulkan bahwa gaya kepemimpinan tidak berpengaruh terhadap motivasi kerja karyawan.

Hal ini tidak sesuai dengan teori jalur sasaran yang dikembangkan oleh Robert House dalam Robbins (2007), bahwa pemimpin memberi kesempatan, menjadwalkan pekerjaan, memberi pedoman untuk mencapai tujuan organisasi. Menurut penelitian (Risambessy dan Swasto, 2012), bahwa motivasi kerja pegawai sangat tergantung kepada motivasi dan perilaku kerja pimpinan. Jika seorang pemimpin bersungguh-sungguh dan penuh komitmen untuk melaksakan suatu pekerjaan, maka secara langsung pegawai atau bawahan akan termotivasi untuk membantu pimpinan dalam melaksakan tujuan organisasi.

Dengan demikian berarti berbeda dengan penelitian terdahulu bahwa terdapat pengaruh langsung gaya kepemimpinan atasan terhadap motivasi kerja pegawai. Dalam penelitian ini ditemukan bahwa gaya kepemimpinan atasan berpengaruh positif tidak signifikan kepada motivasi kerja pegawai. Hal ini dimungkinkan karena pimpinan struktural paling lama menjabat selama 2 periode atau 8 tahun, namun dalam prakteknya setiap satu periode pimpinan struktural akan dirotasi dibagian lain. Hal inilah yang menyebabkan karyawan tidak begitu terpengaruh oleh siapapun pemimpinannya maka pekerjaan akan tetap dilaksanakan dan tidak mempengaruhi motivasi pegawai.

Kedua. Pengaruh komitmen organisasi terhadap motivasi kerja karyawan. Pengaruh komitmen organisasi terhadap motivasi kerja karyawan dalam penelitian ini adalah berpengaruh positif dan signifikan dengan nilai koefisien 0.587 pada $\mathrm{p}<0.05$, yaitu 0.000 maka dapat disimpulkan bahwa komitmen organisasi berpengaruh signifikan terhadap motivasi kerja karyawan.

Menurut Romzek (1990) bahwa peningkatan komitmen organisasi merupakan suatu hal yang sangat penting bagi motivasi dan kualitas pegawai yang bekerja disektor publik karena pelayanan publik membutuhkan tingkat komitmen yang baik. Dari penelitian sedigheh Iranmanesh (2014) terdapat hubungan posistif komitmen organisasi terhadap motivasi kerja.

Dengan demikian, penelitian ini menunjukkan bahwa ada pengaruh langsung komitmen organisasi terhadap motivasi kerja pegawai. Penelitian ini juga membuktikan seperti penelitian yang telah dilakukan (Iranmanesh Sedigheh.2014) menemukan fakta bahwa terdapat korelasi posistif dan signifikan antara komitmen organisasi dan motivasi kerja pegawai.

Model 2. Dalam model 2 sebagai variabel independen adalah motivasi kerja dan variabel dependen adalah kinerja karyawan. Berdasarkan hasil pada tabel diperoleh nilai $\mathrm{R}^{2}$ sebesar 0.442 , hal ini menunjukkan bahwa variabel independen yaitu motivasi kerja pegawai, hanya mampu menjelaskan variabel dependen yaitu kinerja pegawai sebesar 44.2 $\%$ sementara siasanya yaitu $55.8 \%$ adalah diluar variable dalam penelitian ini. 
Pertama. Pengaruh motivasi kerja terhadap kinerja karyawan. Pengaruh motivasi kerja terhadapkinerja karyawan dalam penelitian ini adalah berpengaruh positif dan signifikan dengan nilai koefisien 0.634 pada $\mathrm{p}<0.05$, yaitu 0.000 maka dapat disimpulkan bahwa motivasi kerja berpengaruh terhadap kinerja karyawan.

Motivasi merupakan kegiatan yang mengakibatkan, menyalurkan, dan mendorong perilaku manusaia. Pemimpin perlu memahami orang-orang berperilaku tertentu agar dapat mempengaruhinya dalam bekerja sesuai dengan keinginan organisasi. Untuk itu ada tiga hal penting yang harus diperhatikan dalam memotivasi bawahan menurut (Hasibuan, 1990) yaitu: (a) Hal-hal yang mendorong pegawai adalah pekerjaan yang menantang yang mencakup perasaan unutk berprestasi, bertanggung jawab, kemajuan dapat menikmati pekerjaan itu sendiri dan adanya pengakuan atas semuanya itu; (b) Hal-hal yang mengecewakan pegawai adalah terutama faktor yang bersifat semu / pura-pura saja pada pekerjaan, peraturan pekerjaan, penerangan, istirahat, sebutan jabatan, hak, gaji, tunjangan dan lain-lainnya; (c) Pegawai kecewa jika peluang untuk berprestasi terbatas. Mereka akan menjadi sensitive pada lingkungannya serta mulai mencari-cari kesalahan.

Teori Maslow mengasumsikan bahwa orang berusaha untuk memenuhi kebutuhan yang lebih pokok (fisiologis) sebelum mengarahkan perilakunya untuk memenuhi kebutuhan yang lebih tinggi (perwujudan diri). Dalam teori ini kebutuhan yang telah dipenuhi secara substansial akan mereda daya motivasinya (Robbins:2003). Menurut penelitian (Eugene Saltson and Sharon, 2015) dalam “ The Mediating and Moderating Effects of Motivation in The Relattionship Between Perceived Organizational Support and Employee Job Performance". menemukan bahwa motivasi baik sebagai mediasi dan variable dalam hubungan dengan prestasi kerja berpengaruh positif terhadap kinerja karyawan

Dengan demikian maka dalam penelitian ini sesuai dengan pendapat peneltian terdahulu, menurut penelitian Anthony Afful 2012 menemukan bahwa faktor utama yang mengurangi semangat untuk kinerja yang baik pegawai di Universitas Teknologi Tarkwa di Ghana adalah motivasi karyawan. Dalam penelitian ini juga menemukan bahwa terdapat pengaruh positif dan signifikan motivasi kerja terhadap kinerja pegawai.

Model 3. Dalam model 3 sebagai variabel independen adalah gaya kepemimpinan dan komitmen organisasi dan variabel dependen adalah kinerja karyawan. Berdasarkan analisis determinasi diperoleh nilai $\mathrm{R}^{2}$ sebesar 0.367 , hal ini menunjukkan bahwa variabel independen yaitu gaya kepemimpinan dan komitmen organisasi pegawai, hanya mampu menjelaskan variabel dependen yaitu kinerja pegawai sebesar $36.7 \%$ sementara siasanya yaitu $63.3 \%$ adalah diluar variabel dalam penelitian ini.

Pertama. Pengaruh gaya kepemimpinan terhadap kinerja karyawan. Pengaruh gaya kepemimpinan terhadap kinerja karyawan dalam penelitian ini adalah berpengaruh positif dan tidak signifikan dengan nilai koefisien 0.052 pada $\mathrm{p}>0.05$, yaitu 0.485 maka dapat disimpulkan bahwa gaya kepemimpinan tidak berpengaruh terhadap kinerja karyawan.

Gaya kepemimpinan adalah perilaku dan strategi, sebagai hasil kombinasi dari falsafah, ketrampilan, sifat, sikap, yang sering diterapkan seorang pemimpin ketika ia mencoba mempengaruhi kinerja bawahannya Tampubolon (2007). Teori jalur sasaran yang dikembangkan oleh Robert House dalam Robbins (2007), bahwa gaya kepemimpinan dapat dibedakan menjadi: (1) Kepemimpinan direktif, yaitu kepemimpinan memberi kesempatan pada pengikutnya untuk mengetahui apa yang diharapkan dari mereka, menjadwalkan pekerjaan yang akan dilakukan dan memberi pedoman yang 
spesifik mengenai menyelesaikan tugas; (2) Kepemimpinan suportif, yaitu kepemimpinan yang ramah dan menunjukkan perhatian kepada para pengikutnya atau bawahannya; (3) Kepemimpinan partisipatif, yaitu gaya kepemimpinan dimana pemimpin berkonsultasi dengan bawahan serta meminta dan menggunakan saran-saran bawahan dalam rangka mengambil keputusan; (4) Kepemimpinan orientasi prestasi, yaitu gaya kepemimpinan yang mengajukan tantangan yang menarik bagi bawahan dan merangsang untuk mencapai tujuan, serta melaksanakannya dengan baik.

Berdasarkan penelitian yang dilakukan Huryren Yeh (2012) gaya pemimpin berpengaruh posisif terhadap kinerja pegawai. Menurut (Risambessy dan Swasto, 2012). Jika seorang pemimpin bersungguh-sungguh dan penuh komitmen untuk melaksakan suatu pekerjaan, maka secara langsung pegawai atau bawahan akan termotivasi untuk membantu pimpinan dalam melaksakan tujuan organisasi. Sikap posistif dan keteladanan pimpinan juga menciptakan dan membangkitkan loyalitas kepada pimpinan dan kepada organisasi. Dengan demikian maka gaya kepemimpinan atasan berpengaruh terhadap kinerja karyawan.

Penelitian ini menemukan bahwa tidakterdapat pengaruh antara gaya kepemimpinan terhadap kinerja karyawan. Penelitian inibertentangan dengan penelitian (Alina Ciobanu \& Armenia androniceanu.2015) yang menemukan bahwa ternyata gaya kepemimpinan atasan adalah faktor yang paling mempengaruhi kinerja Pegawai Negeri Sipil di Rumania

Dalam data penelitian ini menunjukkan bahwa bahwa nilai koefisien regresi variable gaya kepemimpinan sebesar 0.052 lebih kecil dari nilai regresi variable motivasi terhadap kinerja pegawai yaitu 0.634 dan nilai $\mathrm{p}$ value $>0.05$. Maka terjadi penurunan pengaruh variable gaya kepemimpinan dan tidak signifikan, dengan demikian maka motivasi kerja merupakan mediasi sempurna gaya kepemimpinan terhadap kinerja pegawai. Hal ini sesuai dengan penelitian (Eugene Saltson and Sharon .2015) dalam "The Mediating and Moderating Effects of Motivation in The Relattionship Between Perceived Organizational Support and Employee Job Performance"'. menemukan bahwa motivasi baik sebagai mediasi dan variable dalam hubungan dengan prestasi kerja berpengaruh positif terhadap kinerja karyawan. Penelitian ini sesuai dengan penelitian (Rohana Thahier, 2014) menemukan bahwa gaya kepemimpinan berpengaruh langsung melalui motivasi.

Kedua. Pengaruh komitmen organisasi terhadap kinerja karyawan. Pengaruh komitmen organisasi terhadap kinerja karyawan dalam penelitian ini adalah berpengaruh positif dan signifikan dengan nilai koefisien 0.467 pada $\mathrm{p}<0.05$, yaitu 0.000 maka dapat disimpulkan bahwa komitmen organisasi berpengaruh signifikan terhadap kinerja pegawai.

Menurut Meyer dan Allen (1991) pada dasarnya pegawai itu ingin berkontribusi untuk mencapai tujuan organisasi dimana untuk mencapai tujuan organisasi ini telah dipengaruhi oleh sifat komitmen yang berbeda-beda sehingga tuntutan tersebut diatas menjadi semakin mendesak pada saat fleksibilitas fiskal mulai menurun seperti sekarang ini, sementara manajer pada lingkungan pemerintah memiliki kemampuan yang sangat terbatas untuk memberikan penghargaan ekstrinsik seperti promosi dan kenaikan gaji/pangkat.

Komitmen organisasi dapat dibedakan menjadi tiga hal (Cheng \& Kalleberg, 1996) yaitu: (1) Kemauan untuk melakukan usaha yang bermanfaat bagi kepentingan oranisasi; (2) Keinginan yang kuat untuk mempertahankan keanggotaan dalam organisasi; (3) Kepercayaan dan penerimaan yang kuat terhadap tujuan dan nilai. 
Penelitian (Boonyada Nasomboon, 2014) dalam "The Relationship among Leadership Commitmen organizational Performance and Employee engagement" dijelaskan bahwa pemimpin yang berkomitmen dengan organisasi, bekerja dan fokus menuju tujuan organisasi mempengaruhi nilai kinerja organisasi. Dengan demikian penelitian ini memperkuat penelitian yang menyatakan bahwa komitmen organisasi mempengaruhi kinerja pegawai.

Dalam data penelitian diatasa juga dapat dilihat bahwa nilai koefisien regresi variable independen komitmen organisasi sebesar 0.467 terhadap variable dependen kinerja pegawai. Nilai koefisien regresinya berkurang dari pada koefisien regresi variabel independen motivasi tehadap variabel dependen kinerja pagawai yaitu 0.634 dengan demikian maka motivasi pegawai adalah memediasi komitmen organisasi tehadap kinerja pegawai.

\section{PENUTUP}

Simpulan. Berdasarkan dari hasil penelitian serta analisis data yang telah dikemukakan pada bab sebelumnya maka bisa ditarik atau diambil kesimpulan sebagai berikut: (1) Gaya kepemimpinan berpengaruhpositiftidak signifikan terhadap motivasi kerja. Hal ini berarti bahwa gaya kepemimpinan tidakberpengaruhterhadap motivasi; (2) Komitmen organisasi berpengaruh positifsignifikan terhadap motivasi kerja. Dengan demikian maka semakin tinggi komitmen organisasi para pegawai maka akan semakin tinggi pula tingkat motivasi kerja pegawai; (3) Motivasi kerja berpengaruhpositif signifikan terhadap kinerja pegawai pegawai. Semakin tinggi motivasi kerja para pegawai maka akan semakin tinggi pula kinerja pegawai; (4) Gaya kepemimpinan berpengaruh positiftidaksignifikan terhadap kinerja pegawai, dengan demikian maka gaya kepemimpinan atasan mempengaruhi secara posistif terhadap kinerja pegawai; (5) Komitmen organisasi berpengaruh positifsignifikan terhadap kinerja pegawai. Hal ini berarti bahwa semakin tinggi komitmen pegawai terhadap organisasi maka kinerja pegawai juga akan meningkat; (6) Gaya kepemimpinan berpengaruh positif tidak signifikan terhadap kinerja dengan mediasi motivasi kerja, dengan demikian maka pengaruh motivasi kerja memediasi secara positif gaya kepemimpinan terhadap kinerja pegawai. Motivasi juga memediasi komitmen organisasi terhadap kinerja pegawai.

\section{DAFTAR RUJUKAN}

Agusthina R, Bambang S, dkk. (2012) "The Influence of transformation leadership style, Motivation, burnout, toward job satisfaction and employee performance". Journal of Basic and Applied Scientific Research. 2(9), 33-42.

Boonyada Nasomboon, (2014)" The Relationship among Leadership Commitment Organizational Performance, and Employee Engagement". International Busines Research. 7(9), 77-90.

Djanaid, Djanalis. (2004) Kepemimpinan Eksekutif: Teori dan Praktek. Malang: Univ. Brawijaya.

Hasibuan. M, (1990) Manajemen Sumber Daya Manusia. Jakarta: PT. Gunung Agung.

Hueryren Yeh, Dachuan Hong, (2012) "The Mediating Effect of Organizational Commitment onLeadership Type and Job Performance". The Journal of Human Resource and Adult Learning. 8 (2), 50-59. 
Jessica, Robert, William, Jeremy. (2014) "Leadership theory and Research in the New Millenium Current theoritical trends and changing perspectives". The Leadership Quarterly, (25), 36-62.

Lewa, K., Iip, Idham, Eka dan Subowo. (2005) "Pengaruh Kepemimpinan, Lingkungan Kerja Fisik dan Kompensasi Terhadap Kinerja Karyawan diPT. Pertamina (Persero) Daerah Operasi Hulu Jawa Bagian Barat Cirebon”. Jurnal SINERGI:Kajian Bisnis dan Manajemen Edisi Khusus.

Marzuki, Sukarno, (2002) "Analisis Pengaruh Perilaku Kepemimpinan terhadap Kepuasan Kerja dan Kinerja Account Officer: Studi Empirik pada Kantor Cab BRI di Wilayah Jawa Timur". Tesis. Program Pasca Sarjana Magister Manajemen Universitas Diponegoro (tidak dipublikasikan).

McNeese-Smith, Donna. (1996) "Increasing Employee Productivity, Job Satisfaction, and Organizational Commitment”. Hospital \& Health Services Administration. 41(2), 160-175.

Nahid naderi, Leyla j, (2014) "The Study of the Effects between Leadership Style, Organization Culture Employees Performance on Leadership Performance International". Journal of Academic Research in Business and Social Science. 4 (12), 187-198.

Nyhan, (1999) "Building learning organisations; Putting theory to test: Lessons from European companies". In European Journal of Vocational Training.

Rivai. Veithzal, (2004) Manajemen Sumber Daya Manusia Untuk Perusahaan dari Teori ke Praktek. Jakarta: Grafindo Perkasa.

Robbins, Stephen P, (2006) Perilaku Organisasi. Edisi kesepuluh. Jakarta: PT Indeks.

Robert L. Mathis dan John. H. Jackson. (2001) Sumber Daya Manusia. Alih bahasa Jimmy Sadeli. Jakarta: Salemba empat.

Siagian, Sondang. (1995) Teori Motivasi dan Aplikasinya. Jakarta: PT Rineka Cipta.

Tampubolon, Biatna. D. (2007) "Analisis Faktor Gaya Kepemimpinan Dan Faktor Etos Kerja Terhadap Kinerja Pegawai Pada Organisasi Yang Telah Menerapkan SNI 19-9001-2001". Jurnal Standardisasi. 9, 106-115.

Yukl, Gary A, 1989. Managerial Leadership: A Review of Theory and Research. Journal of Management. 15 (2), 251-289.

Meyer, J and N. Allen. (1991) "Testing The "Side Bet Theory" Of Organizational Commitment: Some Methodological Considerations". Journal of Applied Psychology.

Robbins, P. Stephen. (2003) Organization Behaviour: Concept, Controversies, Aplications. Seventh Edition. Prentice Hall Inc.

A.A. Anwar Prabu Mangkunegara. (2001) Manajemen SDM Perusahaan. Bandung: Remaja Rosda Karya.

Dessler .Garry. (2006) Manajemen Sumber Daya Manusia. Jakarta : Indeks.

Uma Sekaran, (2006) Metodologi Penelitian untuk Bisnis. Edisi 4. Buku 1. Jakarta: Salemba Empat.

Romzek, B.S. \& Dunbicvk, J.M. (1990) Accountability in The Public Sector. Connectictut: Kumarian Press. 